\title{
Renewable Energy Demand, Financial Reforms and Environmental Quality in West Africa
}

Bright Obuobi ( $\square$ obuobibright@gmail.com )

Nanjing Forestry University https://orcid.org/0000-0002-5271-7420

Yifeng Zhang

Nanjing Forestry University

\section{Emmanuel Nketiah}

Nanjing University of Science and Technology

Gibbson Adu-Gyamfi

Nanjing University of Science and Technology School of Economics and Management

Dan Cudjoe

Nanjing University of Information Science and Technology

\section{Research Article}

Keywords: Renewable Energy Demand, Financial Reforms, Economic Growth, Environmental Quality, West Africa

Posted Date: November 1st, 2021

DOI: https://doi.org/10.21203/rs.3.rs-1020423/v1

License: (c) (i) This work is licensed under a Creative Commons Attribution 4.0 International License.

Read Full License 


\section{Renewable Energy Demand, Financial Reforms and Environmental Quality in}

\section{West Africa}

\section{${\text { Bright Obuobi }{ }^{\mathbf{a}^{*}} \text {, Yifeng Zhang }}^{\mathrm{b}}$, Emmanuel Nketiah' ${ }^{\mathrm{c}}$, Gibbson Adu-Gyamfi ${ }^{\mathrm{c}}$, Dan Cudjoe $^{\mathrm{d}}$}

${ }^{\mathrm{a} C}$ College of Economics and Management, Nanjing Forestry University, Nanjing, Jiangsu, 210037, China

${ }^{\mathrm{b} C e n t r e ~ f o r ~ E c o l o g i c a l ~ C i v i l i z a t i o n ~ a n d ~ R u r a l ~ R e v i t a l i z a t i o n, ~ N a n j i n g ~ F o r e s t r y ~ U n i v e r s i t y, ~ N a n j i n g ~ J i a n g s u, ~} 210037$

${ }^{\mathrm{c} S}$ School of Economics and Management, Nanjing University of Science and Technology, Xuanwu

District, Nanjing, Jiangsu, 210094, China

${ }^{\mathrm{d} S c h o o l ~ o f ~ B u s i n e s s, ~ N a n j i n g ~ U n i v e r s i t y ~ o f ~ I n f o r m a t i o n ~ S c i e n c e ~ \& ~ T e c h n o l o g y, ~ P u k o u ~ D i s t r i c t, ~ N a n j i n g, ~}$ Jiangsu, 210044, China

Corresponding author; Bright Obuobi, College of Economics and Management, Nanjing Forestry University, Nanjing, Jiangsu, 210037, China; obuobibright@gmail.com*

\section{Abstract}

Sustainable Development Goal (SDG-7) stipulates the need for clean energy, reduced carbon emissions, prevention of environmental degradation, promotion of biodiversity, and ecosystem preservation. Towards achieving these goals, this study provides new evidence on the causal link between renewable energy demand, financial reforms, economic growth, foreign direct investment, and environmental quality among emerging West African economies. The study adopted the Fully Modified Ordinary Least Squares, Dynamic Ordinary Least Squares, Pooled Mean group estimation and Granger causality test for its analysis. It was found that renewable energy demand has been favorable to the environmental health of West African economies. Also, financial reforms made within the region contributed to increasing the ecological footprints of the region. Direct investments from foreign companies showed encouraging results as it improves the environment quality. We also found a unidirectional causality from ecological footprints to renewable energy demand and financial reforms but a bidirectional relationship with economic growth and foreign 
direct investment. Moreover, it was evident that ecological footprints granger causes financial

27 reforms and economic growth but not vice versa. Policy recommendations outlined encourages governments and policy-makers to embark on intensive clean energy technologies and effective

29 green financial reforms to help achieve Sustainable Development Goals.

Keywords: Renewable Energy Demand, Financial Reforms, Economic Growth, Environmental Quality; West Africa

\section{Introduction}

34 The significant share of fossil energy in our current energy structure has skyrocketed greenhouse gas emissions (Zhang et al. 2020). Carbon dioxide $\left(\mathrm{CO}_{2}\right)$ emissions from fossil fuels and other gases are a key contributor to greenhouse gas emissions and their consequences (Xu et al., 2020;

37 Yang, et al., 2015). $\mathrm{CO}_{2}$ emissions pose a significant risk to biodiversity as well as long-term sustainability (Nathaniel and Iheonu 2019). It is unfortunate that human activities are still the dominant source of global greenhouse gasses ( $\mathrm{Li}$ et al. 2019). It has been a never-ending debate about $\mathrm{CO}_{2}$ emissions and global warming ever since the turn of the century (Liu and Xiao 2018)

41 prompting coordinated worldwide action from a variety of sources.

42 Energy demand is constantly increasing in production and consumption due to increasing 43 population density and industrialization. Most of the world's energy resources are fossil fuels 44 including natural gas, coal and oil ( Khan et al., 2020; Shahbaz et al., 2021). Evidently, increasing 45 fossil fuel consumption proportionately increases $\mathrm{CO}_{2}$ emissions in the atmosphere, which 46 eventually promotes environmental pollution (Khan et al., 2020). Pollution resulting from $\mathrm{CO}_{2}$

47 emissions from diverse sources has impacted on human health adversely and contributes to 48 mortality (Nathaniel and Adeleye 2021). In Africa, the high mortality rate makes it even more 
49 alarming (WHO 2015). In view of this, low-carbon and green energy production has become a 50 prevalent trend due to these global challenges (Bauer et al. 2016; Fang et al. 2020). With the 51 public's knowledge on global $\mathrm{CO}_{2}$ emissions, new technical ways to lowering pollution, fossil fuel 52 usage, and improving efficacy in energy demand have become critical (Shahbaz et al. 2021). To 53 ensure a green future environment, we must move from traditional fossil fuel energy to renewable 54 energy (Zhang et al. 2021) and the greatest fundamental hurdle to overcome in solving this feasible 55 task is the cost of production and other financial restrictions (Shahbaz et al. 2021).

56 Fortunately, some studies have found that financial development is critical in addressing 57 environmental pollution through renewable energy generation (Destek and Sarkodie, 2019; 58 Katircioğlu and Taşpinar, 2017; Sarkodie and Strezov, 2019; Xu et al., 2020). By improving the environment and promoting environmentally friendly activities through research, good financial systems can help to reduce environmental deterioration and facilitate clean technology investments

61 in renewable energy projects (Zhang 2011). Therefore, it becomes important for countries with 62 long-term visions to have a well-developed financial system, which prioritizes a green economy.

63 To combat this threat, literature on this subject recommend that African economies focus on clean, 64 renewable energy sources, reduce emissions, and improve environmental quality (Nathaniel and 65 Iheonu 2019; Zhang et al. 2019). Oil, natural gas, and other natural resources with high emissions 66 are often produced by developing countries, including those in Africa (Khan et al. 2020a). Africa 67 is known for its abundance of clean energy sources, but its substantial reliance on non-renewable energy sources, which deteriorate the environment is concerning (Aliyu et al. 2018; da Silva et al.

69 2018). With Africa exploring a free trade agreement, research has become extremely important as 70 this agreement is expected to create $\$ 3.4$ trillion in combined GDP and reduce red tape and 71 streamline customs for a total of $\$ 292$ billion in potential revenue benefits (WorldBank 2021). 
72 This calls for financial reforms in various sectors, renewable energy investments and foreign direct

73 investments. Also, a call for studies that consider such a prominent course and sustainability,

74 especially in this era is much needed as it is rarely available. Narrowing this problem, West African

75 economies share many things in common as the countries in the region embark on a journey to

76 create a common currency (Eco). This will have a greater impact on their investment trend, trade,

77 financial reforms and energy usage. As a result, this study is narrowed to some selected countries

78 in the West of Africa to enhance a deeper analysis.

79 Despite the numerous studies on this subject, a variation of research methods is necessary to 80 generate new insights and to avoid distorted findings, especially in the African perspective. As a

81 result, this study provides three significant contributions to the subject. First, the study looks into

82 the influence of renewable energy demand (RED), financial reforms (FR) and economic growth

83 (EG) on West Africa's environmental health. Second, some researches have been conducted on

84 RED, EG together with other common elements but unfortunately, the causal relationship between

85 RED, FR, EG and environmental quality have not been examined. This is extremely significant, 86 particularly in the West African context, and this study aims to address that gap. Lastly, unlike 87 earlier research in the field, which utilized only carbon emissions (negative measure) to estimate 88 environmental health, this study used ecological footprint (EF) (positive measure) to assess West89 African countries' environmental health. EF has a more comprehensive, broader, and better 90 measure of environmental health compared to $\mathrm{CO}_{2}$ emissions (Rudolph and Figge 2017; Destek 91 and Sinha 2020). Fig. 1 below shows West Africa's ecological footprints. 


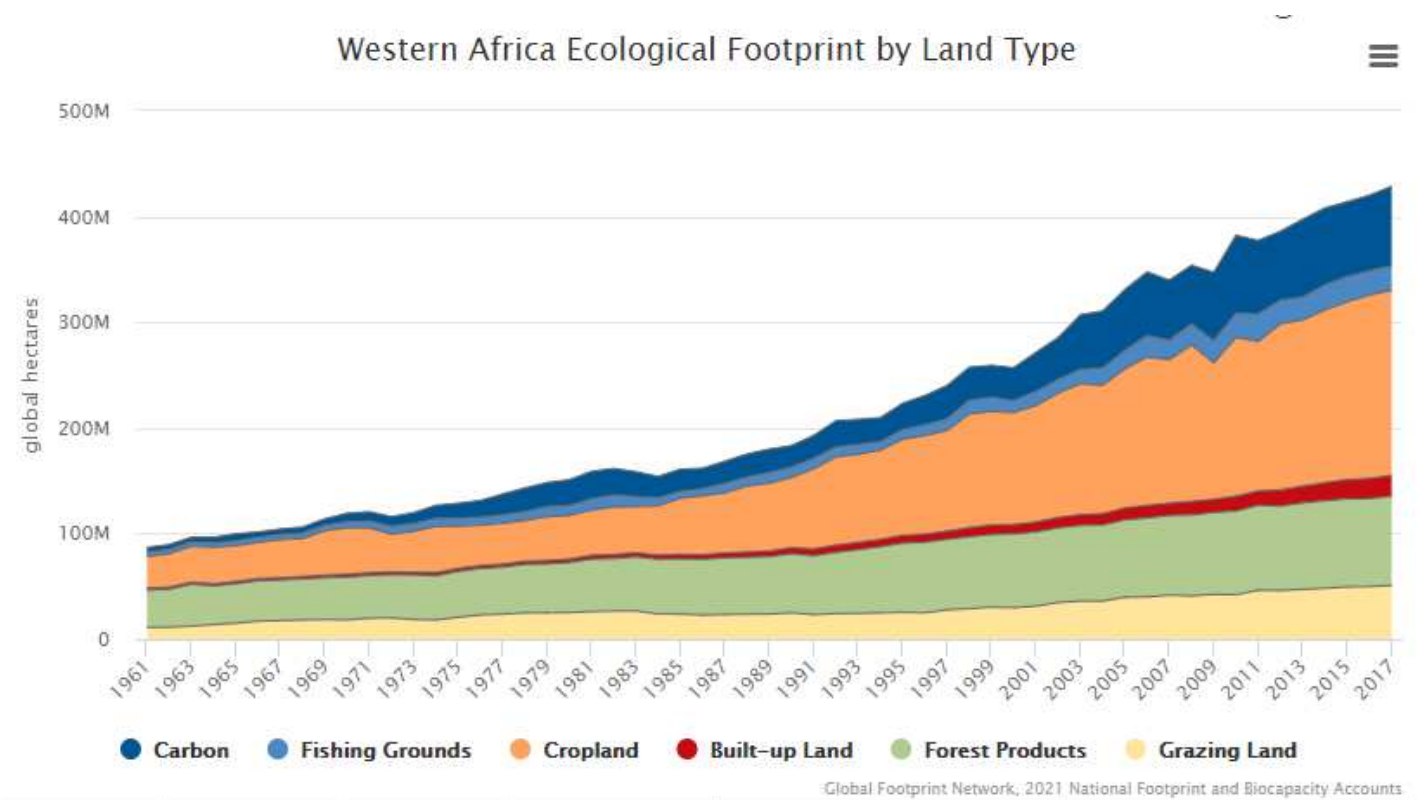

Fig. 1. West Africa's ecological footprints

\section{2. Literature Review}

95 Concerning reducing climate change and improving environmental quality, many scholars have

96 attached importance to it and focused on identifying and assessing the possible factors that are

97 likely to influence carbon emission and eventually decrease the environments' quality in general.

98 Table 2 below summarizes some major studies conducted in recent years as far as environmental

99 quality, renewable energy, financial developments, and economic growth are concerned.

100 Table 2: Some major studies on environmental quality, renewable energy, financial developments 101 and economic growth (I think you can put your study's information in the last part of this Table to 102 inform readers about the difference between your study and existing ones)

\begin{tabular}{|c|c|c|c|}
\hline Author (s) & Country/Area & Methodology used & Major/Related Findings \\
\hline (Chiu and Chang 2009) & OECD & Panel Threshold & RE has a negative impact on $\left(\mathrm{CO}_{2}\right)$ \\
\hline (Zhang 2011) & China & $\begin{array}{c}\text { Cointegration theory, } \\
\text { Granger causality test, } \\
\text { variance decomposition }\end{array}$ & FD increases $\mathrm{CO}_{2}$ \\
\hline (Acaravci and Ozturk 2012) & Turkey & $\begin{array}{c}\text { Granger causality } \\
\text { models }\end{array}$ & FD has no effect on $\mathrm{CO}_{2}$ \\
\hline (Mahesh and Shoba Jasmin 2013) & India & Review & RE has unidirectional effects on $\mathrm{CO}_{2}$ \\
\hline (Dong et al. 2017) & BRICS & AMG & RE has a negative effect on $\mathrm{CO}_{2}$ \\
\hline
\end{tabular}




\begin{tabular}{|c|c|c|c|}
\hline (Balsalobre-Lorente et al. 2018) & EU-5 countries & Least square Models & $\begin{array}{c}\text { EG has a negative impact on } \mathrm{CO}_{2}, \mathrm{RE} \text { has positive } \\
\text { effect on } \mathrm{CO}_{2}\end{array}$ \\
\hline (Acheampong 2018) & 116 countries & GMM & $\begin{array}{c}\text { EG negatively impact } \mathrm{CO}_{2} \text {, EC has negative effect on } \\
\text { EF }\end{array}$ \\
\hline (Liu and Xiao 2018) & 69 Countries & VECM, FMOLS, DOLS & EG increases EF \\
\hline (Shahbaz et al. 2018) & Japan & ARDL & $\mathrm{EC}$ and $\mathrm{EG}$ drives $\mathrm{CO}_{2}$ \\
\hline (Nguyen and Kakinaka 2019) & 107 countries & Panel Cointegration & RE has a negative effect on EF \\
\hline (Khan et al. 2019) & 192 countries & $\begin{array}{l}\text { Panel Quantile } \\
\text { regression }\end{array}$ & FD increases $\mathrm{CO}_{2}$ \\
\hline (Sarkodie and Strezov 2019) & $\begin{array}{l}5 \text { developing } \\
\text { countries }\end{array}$ & $\begin{array}{l}\text { Driscoll-Kraay standard } \\
\text { errors, } U \text { test estimation } \\
\text { approach and panel } \\
\text { quantile regression with } \\
\text { non-additive fixed- } \\
\text { effects. }\end{array}$ & $\mathrm{EC}$ increase $\mathrm{CO}_{2}, \mathrm{FD}$ degrades the environment \\
\hline (Acheampong et al. 2019) & $\begin{array}{l}46 \text { Sub-Saharan } \\
\text { countries }\end{array}$ & $\begin{array}{c}\text { Fixed and Random } \\
\text { effect estimation } \\
\text { technologies }\end{array}$ & $\begin{array}{l}\text { RE has unidirectional effect on } \mathrm{CO}_{2} \text {, FDI has negative } \\
\text { effects on } \mathrm{CO}_{2}\end{array}$ \\
\hline (Arshad Ansari et al. 2020) & $\begin{array}{l}37 \text { Asian } \\
\text { countries }\end{array}$ & GMM & $\begin{array}{l}\text { EG has negative effect on EF, EC has negative effect } \\
\text { on EF }\end{array}$ \\
\hline (Khan et al. 2020b) & G7 countries & $\begin{array}{l}2^{\text {nd }} \mathrm{G} \text { Panel } \\
\text { cointegration }\end{array}$ & $\begin{array}{l}\text { EG has a positive effect on } \mathrm{CO}_{2} \text {, Financial } \\
\text { developments has a negative effect on } \mathrm{CO}_{2}\end{array}$ \\
\hline (Aziz et al. 2020) & Pakistan & Quantile ARDL & RE decreases EF \\
\hline (Baz et al. 2020) & $\begin{array}{l}\text { China, India, } \\
\text { Pakistan }\end{array}$ & DOLS, FMOLS & EG increases EF \\
\hline (Shen et al. 2021) & China & CARDL & FD has a unidirectional relationship with $\mathrm{CO}_{2}$ \\
\hline (Destek and Sinha 2020) & $24 \mathrm{OECD}$ & $\begin{array}{l}\text { FMOLS, DOLS, and } \\
\text { CCEMG }\end{array}$ & RE abates environmental degradation \\
\hline (Nathaniel and Adeleye 2021) & $\begin{array}{l}44 \text { African } \\
\text { countries }\end{array}$ & $\begin{array}{l}\text { Static and dynamic } \\
\text { econometric techniques }\end{array}$ & FD accelerates environmental degradation \\
\hline
\end{tabular}

103 Note: $R E$ is renewable energy, $F D$ is financial developments, $\mathrm{CO}_{2}$ is carbon emissions, EG is economic growth, EC

104 is energy consumption, EF is ecological footprints,

105

106 Considering the objectives of this research, various research has been done, analyzing factors that

107 affect environmental quality from the international level decentralized through to the industrial

108 level. This topic has gotten much attention in the last decade or two, which provides enough of a

109 foundation for more studies to enhance the environment's quality. Given this, it is no surprise that

110 the impact of many variables on the environment has piqued economists' and environmentalists'

111 interest. Furthermore, scholars use a variety of methodologies and techniques to address the 
112 environmental problem at different levels. EG has been the biggest impact among the different

113 parameters employed in recent studies on $\mathrm{CO}_{2}$ and environmental degradation (Ma et al. 2019;

114 Khan et al. 2020a; Nathaniel and Adeleye 2021). The next section reviews various literature on

115 renewable energy demand and financial reforms on environmental quality which forms the core 116 part of this study.

\section{$117 \quad 2.1$ Environmental quality measurement}

118 Some studies are directed to the relationship among EG, energy use, as well as environmental 119 deterioration for more than four decades, using models developed within the EKC structure 120 (Destek and Sinha 2020). Numerous indicators of environmental health is adopted, including 121 (Jayanthakumaran and Liu 2012) with sulfur dioxide, (Khan et al. 2018, 2019; Abokyi, E., Appiah-

122 Konadu, P., Abokyi, F., Oteng-Abayie 2019; Sarkodie and Ozturk 2020) with $\mathrm{CO}_{2}$ emissions, and 123 (Aydin et al. 2019; Destek and Sinha 2020; Nathaniel and Adeleye 2021) with EF. EF is a 124 favorable indicator, while the first two are negative indicators. Due to the criticism leveled against $125 \mathrm{CO} 2$ emissions, recent research have focused on $\mathrm{EF}$ as an indicator of environmental quality 126 (Altıntaş and Kassouri 2020; Arshad Ansari et al. 2020; Baz et al. 2020; Destek and Sinha 2020; 127 Sharif et al. 2020; Nathaniel and Adeleye 2021)

\subsection{Renewable energy Demand (RED) and Environmental quality}

129 The function of RED has been explored since it significantly impacts carbon emissions. $\mathrm{CO}_{2}$ 130 emissions and $\mathrm{EF}$ are the two most frequent indicators used by academics to represent 131 environmental quality. In terms of renewable energy demands, (Shafiei and Salim 2014) 132 discovered that as OECD countries' demand for renewable energy grows, carbon emissions 133 decrease. In (Işık et al. 2019) study, a positive effect of renewable energy demand on carbon 134 emission was found in the United States. A similar study in Sub-Saharan Africa by (Hanif 2018) 
135 examined the relationship between carbon dioxide emissions caused by fossil fuels, renewable

136 energy use, solid fuel consumption, and urban expansion. It was revealed that renewable energy

137 greatly diminishes $\mathrm{CO}_{2}$ emissions in the countries studied. According to (Zoundi 2017), the

138 extortion of renewable energy consumption has some constraints regarding reduced economic

139 growth and conditioned countries. Also, (Jebli and Youssef, 2015) demonstrated that, renewable

140 energy consumption increases EG and eventually affects the environment's quality. Similarly,

141 (Apergis and Payne 2014) discovered a long-run link between $\mathrm{CO}_{2}$ emissions and renewable

142 energy demand. With the increasing impact of renewable energy consumption on the environment,

143 (Sinha et al. 2018) assert that the initial cost of renewable energy investment to fulfill demand

144 inhibits developing nations from focusing entirely on renewable energy sources. Using data from

145 five developing nations, (Sarkodie and Strezov 2019) examined the energy- $\mathrm{CO}_{2}$ emissions nexus

146 and found that energy use increases $\mathrm{CO}_{2}$. (He et al. 2019) looked at the effect of energy demand

147 and EG on EF in Malaysia and discovered that the former contributed significantly to the latter.

148 Energy demand, population, and EG are the main causes of environmental degradation in OPEC

149 countries, according to (Fakher 2019)

\subsection{Financial reforms and Environmental quality}

151 Several prior research have adopted proxies of financial reforms in different regions and 152 established its relationship with environmental quality. It was determined by (Al-Mulali and Binti 153 Che Sab 2012) that increased $\mathrm{CO}_{2}$ emissions result from financial development. According to 154 (Zhang, 2011), financial institutions have a vital role in lowering environmental pollution. 155 Similarly, (Tamazian and Bhaskara Rao 2010) argues that financial development impact on $\mathrm{CO}_{2}$ 156 emissions adversely, although (Zhang 2011) claims a positive impact in China. (Acaravci and 157 Ozturk 2012), on the other hand, assert that there is no effect of financial developments on $\mathrm{CO}_{2}$ in 
158 Turkey. According to (Sarkodie and Strezov 2019), a well-functioning financial system 159 encourages FDI inflows, which deteriorate environmental quality. (Majeed and Mazhar 2019) 160 studies on 131 countries reveal that, financial development enhances environmental quality by 161 decreasing EF and energy demand. However, they found that FDI and GDP accelerate EF. There 162 has been a heated debate in the literature on FDI and its effects on environmental quality, 163 renewable energy usage, and other aspects. According to (Stretesky and Lynch 2009), FDI in the 164 form of technology commodities can assist the reduction of air pollution. Similarly, different 165 scholars opine that, FDI reduces air pollution and increases economic growth by raising an 166 economy's productivity, resulting in high energy usage. Furthermore, polluting firms invest in 167 developing nations to minimize production costs since these economies lack proper environmental 168 rules that allow them consume more energy, resulting in higher $\mathrm{CO}_{2}$ emissions (Acharyya, 2009; 169 Lau et al., 2014). Therefore, these deficiencies in environmental rules attract such FDIs and raise $170 \mathrm{CO}_{2}$ emissions. In view of this, the relevance of FDI is examined in the study.

171 Based on the literatures reviewed, we identify a methodology gap and also discrepancies between 172 findings in the global setting and the African context. As a result, we develop a conceptual 173 framework for the study involving other relevant control variables used in similar studies as seen 174 in Fig. 2. 


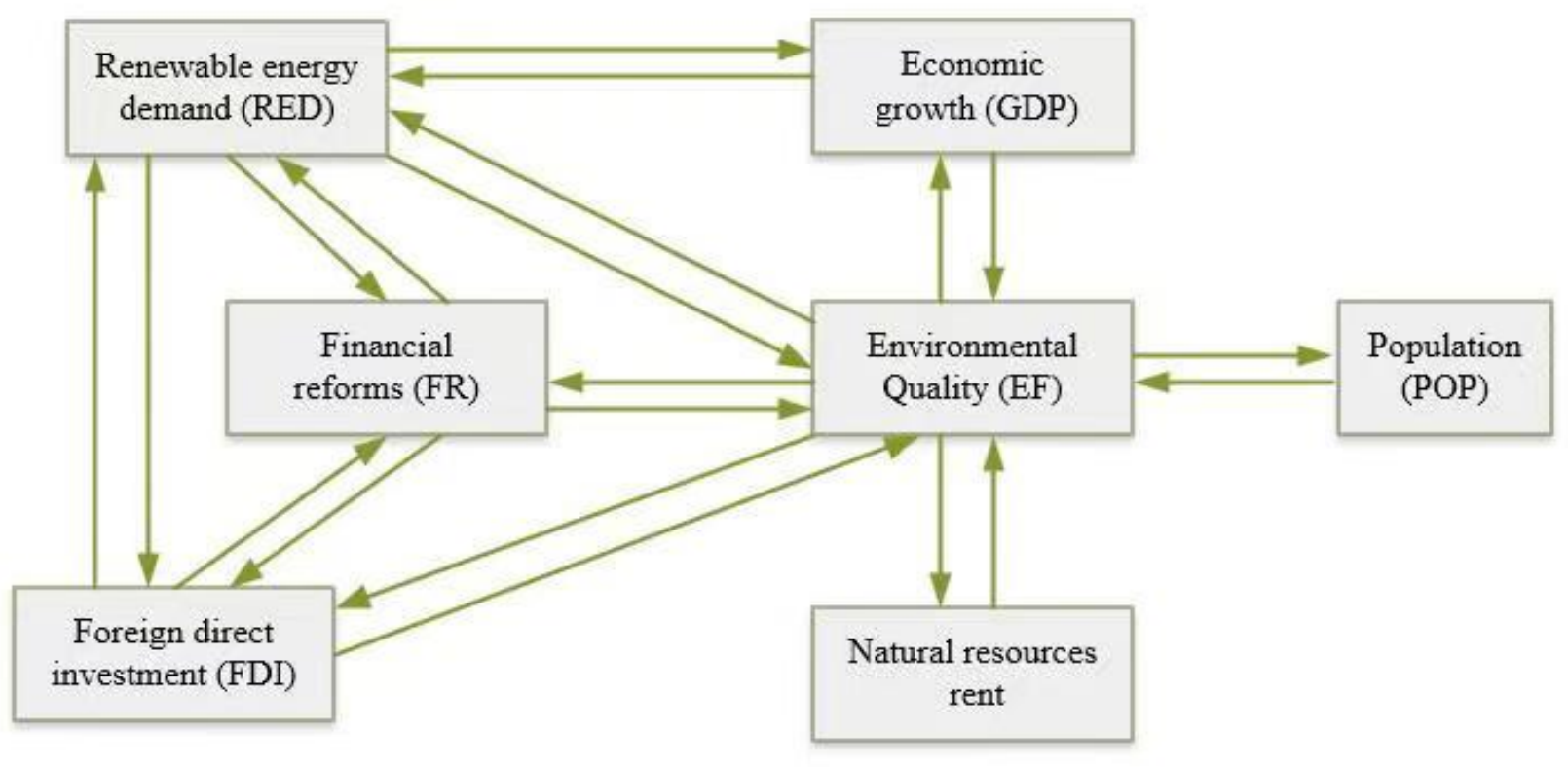

Fig. 2: Conceptual framework

\section{3. Data and Methodology}

\section{$179 \quad$ 3.1 Data collection and variables used}

180 The study adopts panel data on 11 West African economies from 1990 to 2017. Countries selected 181 were based on data available to meet the objectives of this research. Table 2 below provides the 182 data used and their variable explanation and their measurement unit and source.

183 Table 2: Variables used and their data sources

\begin{tabular}{|l|l|l|l|}
\hline Abbreviation & Name of variable & Unit of measurement & Data Source \\
\hline EF & Ecological footprints & Ecological footprints (gha) & Global Footprints Network (2021) \\
\hline RED & Renewable energy demand & $\begin{array}{l}\text { Renewable energy consumption } \\
(\% \text { of total final energy } \\
\text { consumption })\end{array}$ & Worldbank 2021) \\
\hline FR & Financial reforms & $\begin{array}{l}\text { Domestic credit to private sector } \\
(\% \text { of EG })\end{array}$ & Worldbank 2021) \\
\hline FDI & Foreign direct investment & $\begin{array}{l}\text { Foreign direct investment, net } \\
\text { inflows }(\% \text { of EG })\end{array}$ & Worldbank 2021) \\
\hline EG & Natural resource rent & EG (current US\$) & Worldbank 2021) \\
\hline NRR & Population & Total Population & Worldbank 2021) \\
\hline POPN & & & Worldbank 2021) \\
\hline
\end{tabular}




\subsection{Empirical model}

186

187

188

189

190

191

192

193

194

195

196

197

The study's theoretical structure was centered on an endogenous model with renewable energy demand, financial reforms, foreign direct investment, natural resource rent, economic growth, and population. Thus, this equation is formulated below (1).

$\mathrm{EF}_{\mathrm{it}}=\alpha_{0}+\beta_{1} \mathrm{RED}_{\mathrm{it}}+\beta_{2} \mathrm{FR}_{\mathrm{it}}+\beta_{3} \mathrm{FDI}_{\mathrm{it}}+\beta_{4} \mathrm{NRR}_{\mathrm{it}}+\beta_{5} \mathrm{EG}_{\mathrm{it}}+\beta_{6} \mathrm{POPN}_{\mathrm{it}}+u_{i}$

Where $\mathrm{EF}$ is ecological footprints, RED is renewable energy demand, FR is financial reforms, FDI represents foreign direct investment, NRR denotes natural resource rent, EG stands for economic growth and POPN represents population. $\left(\beta_{1}-\beta_{6}\right)$ are the parameter estimates, $\alpha$ is the intercept, $t$ is the period, and $u$ represents the error term.

In achieving efficient, dependable, and consistent outcomes, and examine the long-term link between variables, we express Eq. (1), to their natural logarithm in Eq. (2).

$\log _{\mathrm{e}}(\mathrm{EF})=\alpha+\sum \mathrm{a} \log _{\mathrm{e}}(\mathrm{RED}, \mathrm{FR}, \mathrm{FDI}, \mathrm{NRR}, \mathrm{EG}, \mathrm{POPN})$

Hence, the functional model can be written as:

$\ln \mathrm{EF}_{\mathrm{it}}=\alpha_{0}+\beta_{1} \ln \mathrm{RED}_{\mathrm{it}}+\beta_{2} \ln \mathrm{FR}_{\mathrm{it}}+\beta_{3} \ln \mathrm{FDI}_{\mathrm{it}}+\beta_{4} \ln \mathrm{NRR}_{\mathrm{it}}+\beta_{5} \ln \mathrm{EG}_{\mathrm{it}}+\beta_{6} \ln \mathrm{POPN}_{\mathrm{it}}+u_{i t} \ldots$

\subsection{Methodology}

The general expectation is that the panel data model disturbances are cross-sectional, especially when the $(\mathrm{N})$ dimension is vast. Ignoring cross-sectional independence could greatly impact unaccounted residual dependence which can lead to inefficiency and a statistically invalid test. Due to the above issues, the study first examined the cross-sectional dependence using Pesaran CD (Pesaran, 2004). Pesaran CD employs rigorous ways to resolve any unnoticed causes or disruptive effects in countries because of economic growth, similar economic indicators, and other common characteristics.

$\mathrm{CD}=\sqrt{\frac{2 T}{N(N-1)}}\left(\sum_{i=1}^{N-1} \sum_{j=i+1}^{N} P^{\prime} i j\right) \equiv N(0,1)$ 
210 T means time period, $\mathrm{N}$ refers to sample size, and $\mathrm{P}^{\prime} \mathrm{ij}$ is the country's sample estimate of cross-

211 sectional correlation errors $\mathrm{i}$ and $\mathrm{j}$ given as

$212 \quad \mathrm{P}^{\prime} \mathrm{ij}=\frac{\sum_{t=1}^{T} u_{i t} u_{i t}}{\left(\sum_{t=1}^{T} u_{i t}^{2}\right)^{1 / 2}\left(\sum_{t=1}^{T} u_{j t}^{2}\right)^{1 / 2}}$

213 Where, $\mathrm{H}_{0}: \mathrm{p}_{\mathrm{ij}}=\mathrm{p}_{\mathrm{ji}}=\operatorname{cor}\left(\mathrm{u}_{\mathrm{it}}, \mathrm{u}_{\mathrm{it}}\right)=0$ for $\mathrm{i} \neq \mathrm{j}$, and the alternative hypothesis as, $\mathrm{H}_{1}: \mathrm{p}_{\mathrm{ij}}=\mathrm{p}_{\mathrm{ji}} \neq 0$

214 for some $\mathrm{i} \neq \mathrm{j}$

\section{$215 \quad 3.4$ Unit root test}

216 We used the augmented Dicker-Fuller (ADF) to analyze variables' stationarity. It is expressed as

$217 \Delta y=a_{i}+p_{i} y_{i, t-j}+\gamma_{1} \bar{y}_{t-1}+\sum_{j}^{k} \gamma_{i j} \Delta \bar{y}_{i, t-j}+\sum_{j=0}^{k} \Delta \bar{y}_{i, t-j}+\varepsilon_{i t}$

218 Where $\bar{y}_{t-1}=\left(\frac{1}{N}\right) \sum_{i=1}^{N} y_{i, t-1}, \Delta \bar{y}_{t}=\left(\frac{1}{N}\right) \sum_{i=1}^{N} y_{i t}$ and $\mathrm{t}_{\mathrm{i}}(\mathrm{N}, \mathrm{T})$ is the t-statistics of the estimates 219 and $\mathrm{P}^{\prime}$ is the individual ADF statistics

220

221

\subsection{Cointegration analysis}

222 To establish the cointegration among the variables used, the Kao and Pedroni cointegration test 223 was adopted. To achieve the objective stated in Eqn. 1, we first apply the Kao cointegrating test.

224 The ADF t-statistics is mathematically expressed as,

225

$\mathrm{ADF}=\frac{{ }^{t} A D F+\left(\frac{\sqrt{6 N \vartheta_{q}}}{2 \vartheta_{0 q}}\right)}{\sqrt{\left(\frac{\vartheta_{0 q}^{2}}{2 \vartheta_{q}^{2}}\right)+\left(10 \vartheta_{0 q}^{2}\right)}}$

226 Where $\vartheta_{a}^{2}=\sum_{u \varepsilon}-\sum_{u \varepsilon} \sum_{\varepsilon}^{-1}, \vartheta_{0 a}^{2}=\Omega_{u}-\Omega_{u \varepsilon} \Omega_{\varepsilon}^{-1}, \Omega$ denotes the long-run covariance matrix and $227{ }^{\mathrm{t}} \mathrm{ADF}$ refers to t-statistic in ADF regression for cointegration.

228 Moving further, the study used confirms the results achieved by the Kao cointegration test through 229 the application of Pedroni, (2004) cointegrating technique. The Pedroni cointegration test is based 230 on intra- and inter-dimensional cointegration with parenthetic lag lengths. It can be expressed 231 mathematically as, 
$233 \alpha_{\mathrm{i}}$ and $\delta_{\mathrm{i}}$ are the intercepts and gradient coefficients and can differ across cross-sections, $\mathrm{t}=1, \mathrm{~T}, \mathrm{i}$

$234=1, \mathrm{~N}, \mathrm{p}=1, \mathrm{EF}, \mathrm{x}$, and $\mathrm{p}$ are considered to be similar and orderly integrated (I(1)). Under the null 235 hypothesis of no cointegration, the residuals $\varepsilon_{\text {it }}$ will be I (1).

\section{$236 \quad 3.6$ Long-run estimates}

237 To generate our variables' long-run estimates, the Dynamic Ordinary Least Square (DOLS) and 238 Fully Modified Ordinary Least Square (FMOLS) for elasticity were prioritized over the traditional 239 Ordinary Least Square (OLS) because the FMOLS is the modification of the OLS. They cater for 240 serial correlation problems as well as the endogeneity bias predominance. Getting rid of 241 Endogeneity issues using a non-parametric method, the regressors and error term are sequentially 242 correlated (Dogan and Seker 2016). As a result, the FMOLS is quite effective. A parametric 243 approach, lags, and leads are also used by the DOLS estimator. The FMOLS approach to 244 measuring the long-run relationship between the variables proposed by (Pedroni 2000) can be 245 expressed as;

$\mathrm{EF}=\omega_{0}+\beta X_{i t}-i+\sum_{j=i}^{j} \gamma_{j} \gamma X_{i t-j}+\mu_{i t}$

247 Where EF refers to the dependent variable Ecological footprints. The $\mathrm{X}_{\mathrm{it}}$ denotes the independent 248 variables used for the study. The long-run variance is given by

$\Omega_{i}=\lim T \rightarrow \infty F\left[\left(\frac{1}{T}\right)\left(\sum_{t}^{T}=1^{u_{i t}}\right)^{\prime}\right]$

250 FMOLS estimator is subsequently extended to Eqn. 11, as indicated below.

$\beta=\frac{1}{n} \sum_{i=1}^{n}\left[\sum_{t=1}^{T}\left(\left(X_{i t}-\bar{X}_{i t}\right)^{2}\right)^{-1}\left(\sum_{t=1}^{T}\left(X_{i t}-\bar{X}_{i t}\right)\right)\left(E F_{i t}-\tau_{\gamma}\right]\right.$

252 Where $\mathrm{EF}=E F_{i t}-\overline{E F e q-}\left(\frac{\widehat{\Omega}_{1,0}}{\widehat{\Omega}_{1,1}}\right) \Delta X_{i t} ;$ and

$$
\hat{\gamma}=\hat{\tau}_{1,0}+\widehat{\Omega}_{1,0}-\left(\frac{\widehat{\Omega}_{1,0}}{\widehat{\Omega}_{1,1}}\right)\left(\hat{\tau}_{1,1}+\widehat{\Omega}_{1,1}\right)
$$

254 Finally, we establish the directional causality among the variables by applying the Pool Mean 255 Group (PMG) estimator and the Granger causality.

\section{Results and Discussion}

\subsection{Descriptive statistics}


259 In Table 3, we display the results of the descriptive statistics conducted for all variables used. The

260 mean, maximum, minimum, volatility, skewness, kurtosis, and distribution normality. The kurtosis

261 indicates that all variables show a platykurtic distribution in determining whether the distribution

262 is too peaked since they are all greater than one (1). Also, RED, FR, FDI and NRR indicate a left-

263 skewed distribution. However, EG, EF and population also show a right-skewed distribution. Also,

264 all of the variables are generally distributed, according to the Jarque-Bera test statistic. All other

265 statistics of the respective variables can be found in Table 3.

\begin{tabular}{cccccccc}
\hline & EF & RED & FR & FDI & NRR & EG & POP \\
\hline Mean & 16.2712 & 4.3211 & 2.2437 & 0.2775 & 2.1804 & 22.3855 & 16.0525 \\
Median & 16.3638 & 4.3766 & 2.4064 & 0.4991 & 2.3158 & 22.1628 & 16.0996 \\
Maximum & 19.1058 & 4.5535 & 3.6929 & 3.4751 & 3.4592 & 27.0271 & 19.0671 \\
Minimum & 13.8303 & 3.7236 & -0.9099 & -6.0888 & 0.6938 & 19.1456 & 13.7701 \\
Std. Dev. & 1.2819 & 0.1845 & 0.7037 & 1.4142 & 0.6237 & 1.6476 & 1.2703 \\
Skewness & 0.2643 & -1.1645 & -0.7703 & -1.2994 & -0.4331 & 0.5718 & 0.2903 \\
Kurtosis & 2.8063 & 3.5963 & 4.1258 & 5.7302 & 2.2767 & 3.3349 & 3.1030 \\
Jarque-Bera & 3.7377 & 68.1495 & 42.9277 & 167.5323 & 15.0164 & 16.7468 & 4.1011 \\
& & & & & & & \\
\hline
\end{tabular}

266

$267 \quad 4.2$ Cross section Dependency test

268 Table 4 displays the results of the cross-section dependency test (CD test). The test was conducted

269 in the various panels option; OLS, fixed effects and random effects. The Table shows the t-

270 statistics with their respective p-values. The null hypothesis indicated no cross-section dependency,

271 and at a significance level of 5\%, the null hypothesis couldn't be rejected. We then conclude that,

272 there is no cross-section dependence among the variables used for the study.

Residual Cross-Section Dependence Test

Null hypothesis: No cross-section dependence in residuals

\begin{tabular}{ccccccc}
\hline Test & \multicolumn{2}{c}{ OLS } & \multicolumn{2}{c}{ Fixed Effects } & \multicolumn{2}{c}{ Random effects } \\
\hline \multirow{3}{*}{ Pesaran CD } & t- value & p-value & t-value & p-value & t- value & p-value \\
& 0.8415 & 0.4000 & -0.1655 & 0.8686 & -0.5718 & 0.5674
\end{tabular}




\subsection{Panel Unit root test}

276 In table 5, the Augmented Dickey-Fuller test results can be seen. This was to test the stationarity 277 of the variables for further analysis. At level, FDI was significant at 1\% level, NRR at 5\% level 278 and POP at 10\% level. All other variables were insignificant at level which we can't reject null 279 hypothesis. The variables were then assessed in their $1^{\text {st }}$ difference under the same test method, 280 and they all became stationary at $1 \%$ level. We can then conclude that, the variables are integrated 281 simultaneously and can be used for econometric modeling.

282 Table 5: Augmented Dicker-Fuller (ADF) Results

\begin{tabular}{lllll}
\hline Test & $\begin{array}{l}\text { Level } \\
\text { statistic }\end{array}$ & Prob. & $\begin{array}{l}\text { Ist Diff. } \\
\text { statistic }\end{array}$ & Prob. \\
\hline EF & 8.7622 & 0.9945 & 156.518 & $0.0000^{* * *}$ \\
RED & 11.7565 & 0.9622 & 107.458 & $0.0000^{* * *}$ \\
FR & 31.7810 & 0.0812 & 97.0939 & $0.0000^{* * *}$ \\
FDI & 62.6479 & $0.0000^{* * *}$ & 111.948 & $0.0000^{* * *}$ \\
NRR & 37.5822 & $0.0204^{* *}$ & 123.255 & $0.0000^{* * *}$ \\
EG & 2.2159 & 1.0000 & 110.043 & $0.0000^{* * *}$ \\
POP & 31.2557 & $0.0910^{*}$ & 141.584 & $0.0000^{* * *}$ \\
\hline
\end{tabular}

Statistical significance: $1 \%$ ***, 5\%** and 10\%* Reject null at 5\% significance

\subsection{Cointegration Test results}

\subsubsection{Kao Residual Cointegration}

286 One of the fundamentals of this study was to determine the existence of long-run relationship among constructs. In Table 6, we used the Kao cointegration test to confirm a long-run association among the variables and are cointegrated. With a p-value of 0.0000 , we accept the alternative hypothesis indicating a long-run association among the variables.

Table 6: Kao Residual Cointegration Test results

Null Hypothesis: No cointegration

\begin{tabular}{lrc}
\hline & t-Statistic & Prob. \\
\hline ADF & -5.640799 & $0.0000 * * *$
\end{tabular}




\subsubsection{Pedroni Residual Cointegration Test results}

294 In testing for the cointegration among the variables, the Pedroni cointegration test was also adopted 295 after the Kao, and the results are displayed in Table 8 shows the results obtained when the Pedroni 296 cointegration test was conducted. In the Table, 11 results are displayed from the test. With all 11 297 results obtained, panel PP-statistic (0.0000, 0.0000) and panel ADF-statistic (0.0000, 0.0000), 298 Group PP-statistic (0.0000) and Group ADF-statistic (0.0000) were found significant at $1 \%$ level. 299 Overall, 6 out of the 11 were significant, which means we can reject null hypothesis of 300 cointegration. This confirms the Kao cointegration test results as the Pedroni panel cointegration 301 test results have a majority of the Pedroni panel cointegration test results rejected the null 302 hypothesis.

Table 7: Pedroni Residual Cointegration Test results

Null Hypothesis: No cointegration

\begin{tabular}{lccrc}
\hline \multicolumn{2}{l}{ Alternative hypothesis: common AR coefs. (Within-dimension) } & \multicolumn{3}{c}{ Weighted } \\
& Statistic & Prob. & Statistic & Prob. \\
\hline Panel v-Statistic & -1.7054 & 0.9559 & -2.0807 & 0.9813 \\
Panel rho-Statistic & 0.7428 & 0.7712 & 1.0642 & 0.8564 \\
Panel PP-Statistic & -6.2833 & $0.0000^{* * *}$ & -5.7752 & $0.0000^{* * *}$ \\
Panel ADF-Statistic & -4.6935 & $0.0000^{* * *}$ & -4.5177 & $0.0000^{* * *}$ \\
Alternative hypothesis: individual AR coefs. (Between-dimension) & & \\
\multicolumn{5}{c}{ Prob. } \\
Group rho-Statistic & Statistic & 1.9849 & 0.9764 & \\
Group PP-Statistic & & -10.8724 & $0.0000^{* * *}$ \\
Group ADF-Statistic & -5.5993 & $0.0000^{* * *}$ & \\
\hline
\end{tabular}

Statistical significance: $1 \%$ ***, 5\%** and 10\%* Reject null at 5\% significance

From Table 8, the results of DOLS and FMOLS have an explanatory power of $99.97 \%$ and $63.5 \%$ respectively. The left-hand side reveals the results from the FMOLS with coefficient, t-statistics and p-values. Likewise, the right-hand side displays the results from the DOLS.

Table 8: DOLS and FMOLS results

Dependent Variable: EF

\begin{tabular}{ccccccc}
\hline & \multicolumn{3}{c}{ FMOLS } & \multicolumn{3}{c}{ DOLS } \\
Variable & Coefficient & t-Statistic & Prob. & Coefficient & t-Statistic & Prob. \\
\hline RED & -0.0428 & -63.1797 & $0.0000^{* * *}$ & -0.4290 & -5.6300 & $0.0000^{* * *}$
\end{tabular}




$\begin{array}{ccccccc}\text { FR } & 0.0390 & 17.6490 & 0.0000^{* * *} & -0.0279 & -0.7727 & 0.4450 \\ \text { FDI } & -0.1952 & -59.8566 & 0.0000^{* * *} & -0.0751 & -10.8537 & 0.0000^{* * *} \\ \text { NRR } & 0.1146 & 74.7870 & 0.0000^{* * *} & 0.1146 & 4.8448 & 0.0000^{* * *} \\ \text { EG } & 0.0747 & 145.0681 & 0.0000^{* * *} & 0.0713 & 2.9669 & 0.0055^{* * *} \\ \text { POP } & 0.8600 & 71071.4400 & 0.0000^{* * *} & 1.0164 & 22.0693 & 0.0000^{* * *}\end{array}$

308 R-squared $\quad 0.635638$ Statistical significance: $1 \%$ \%**, 5\%**and 10\%* Reject null at 5\% significance 0.999743

309 Regarding RED and environmental quality measured in EF, we found a negative (-0.0428)

310 significant (0.0000) relationship. This is confirmed by the DOLS results which also reveals a

311 negative significant relationship between the variables. This means that a $1 \%$ increase in the

312 demand for renewable energy in West Africa improves the region's environmental quality by

$3130.0428 \%$ (FMOLS) and $0.429 \%$ (DOLS). From this, we could deduce that West African

314 economies demand and for renewable energy has been favorable to their EF. This is consistent

315 with the works of (Apergis and Payne 2014; Zhou and Li 2019; Khan et al. 2020a) who found

316 renewable energy usage to declines $\mathrm{CO}_{2}$ emissions and (Nguyen and Kakinaka 2019; Aziz et al.

317 2020) who found renewable energy consumption to decrease EF.

318 On FR and developments in the region, our FMOLS results revealed a significant positive impact

319 on environmental quality. This means that $1 \%$ increment in FR increases their EF by $0.039 \%$,

320 which declines environmental quality. This results align with (Zhang 2011) and (Nathaniel and

321 Adeleye 2021) who concluded that financial developments degrades the environment. The DOLS

322 couldn't confirm as it indicated an insignificant impact just like (Acaravci and Ozturk 2012) who

323 found no impact between FR and environmental quality in Turkey. FDI, which forms an integral

324 part of any developing country, was found to negatively affect environmental quality among West

325 African economies. This indicates that any $1 \%$ increment in direct investment from foreign

326 companies improved the environmental quality by $0.1952 \%$ (FMOLS) and $0.0751 \%$ (FMOLS).

327 This may be attributed to the fact that, as the world goes towards sustainability, these economies 
are getting interested in green investments that develop the country and promote the quality of the environment. (Khan et al. 2020a) found similar results. NRR, a very important variable among West African economies, was identified to have impacted EF positively. This is confirmed from the table by FMOLS and DOLS with 0.1146 coefficients. This indicates that the compensation

332 (rents) from the natural resources keeps causing harm to the environment. As the rents increase, 333 environmental quality decreases by EF. Economic growth measured by GDP in US\$ shows a 334 positive significant (FMOLS=0.0747, DOLS=0.0713) relationship with environmental quality. A $3351 \%$ increase in the growth of West African economies increases their environmental degradation. 336 As a result of deforestation and mining, the majority of Africa's economies rely on these industries, 337 which could have an impact on their environment. This finding conforms to (Liu and Hao 2018), 338 who found economic growth to increase EF among 69 countries. However, it is inconsistent with 339 (Dong et al. 2017) and (Balsalobre-Lorente et al. 2018), who also found economic growth to 340 decrease environmental quality measured by $\mathrm{CO}_{2}$ among BRICS and EU-5 countries, respectively. 341 The population and its growth in West Africa are found to positively affect the quality of the 342 environment by FMOLS (0.8600) and DOLS (1.0164). As the population of the region increases, 343 so does their EF.

344 The results for the Pooled Mean group estimates are displayed in Table 9. The study adopted it to 345 determine the short and long-run directional causality among some key variables used for the study. 346 The PMG estimator allows short-term dynamics to differ between countries while limiting the 347 long-term coefficients for all cross-sections data.

348 Table 9: Results of Pooled Mean Group (PMG)

\begin{tabular}{lll}
\hline Causality Test & & \\
\hline Estimator & Short-Run & Long-Run \\
\hline & $\mathrm{EF} \longrightarrow \mathrm{FR}$ & $\mathrm{EF} \leftrightarrow \mathrm{FR}$ \\
$\mathrm{PMG}$ & $\mathrm{EF} \longrightarrow \mathrm{RED}$ & $\mathrm{EF} \leftrightarrow \mathrm{RED}$ \\
& $\mathrm{EF} \leftrightarrow \mathrm{EG}$ & $\mathrm{EF} \leftrightarrow \mathrm{EG}$
\end{tabular}




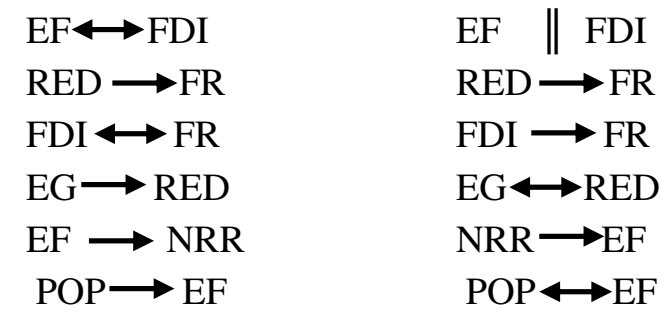

$\|$ means no directional causality, $\longrightarrow$ means unidirectional causality, $\longleftrightarrow$ means bidirectional causality

350 From Table 9, the short-run causalities can be found on the left side and the long-run on the other 351 side. On the short-run, we found a unidirectional causality from EF to FR, RED and NRR. Also, a 352 unidirectional causality was found from RED to FR, EG to RED and population to EF. However, 353 EF and EG, EF and FDI, FDI and FR were all bidirectional causalities. This means they influence 354 each other.

355 On the long-run, we noticed similar and different results. Only RED to FR, FDI to FR and NRR 356 to EF had a unidirectional causal relationship. EF has a bidirectional relationship with RED, FR, 357 EG and population. Also, a bidirectional relationship was found between EG and RED. Our study 358 found no causal relationship between EF and FDI in the long run.

359 We adopted the Granger causality test to enhance further our study and its findings (Granger 1969). 360 Granger Causality is widely used because of its computational simplicity. Also, as other tests 361 determine what causes what, Granger causality determines whether or not one variable is useful to 362 forecast another variable. We used this to test if the variables used can be useful when forecasting 363 the other variables, and the results are seen in Table 10.

Table 10: Pairwise Granger Causality Tests Results

\begin{tabular}{lrlll}
\hline \multicolumn{1}{c}{ Null Hypothesis: does not granger cause } & F-Statistic & Prob. & \\
\hline FDI to EF & 0.2454 & 0.6208 & \\
EF to FDI & 0.1383 & 0.7103 & \\
FR to EF & 0.0037 & 0.9513 & \\
EF to FR & 5.8313 & 0.0164 & $* * *$ \\
EG to EF & 0.0441 & 0.8339 & \\
EF to EG & 4.6357 & 0.0321 & $* *$ \\
NRR to EF & 0.1161 & 0.7335 & \\
EF to NRR & 0.2624 & 0.6088 & \\
POP to EF & 5.6998 & 0.0176 & $* * *$ \\
EF to POP & 4.6480 & 0.0319 & $* *$ \\
RED to EF & 0.1430 & 0.7056 &
\end{tabular}




\begin{tabular}{lrlll} 
FR to FDI & 0.4075 & 0.5238 & \\
FDI to FR & 7.2455 & 0.0076 & $* *$ \\
EG to FDI & 0.7046 & 0.4020 & \\
FDI to EG & 6.3790 & 0.0121 & $* * *$ \\
NRR to FDI & 2.0998 & 0.1485 & \\
FDI to NRR & 0.0164 & 0.8983 & \\
RED to FDI & 8.1704 & 0.0046 & $* * *$ \\
FDI to RED & 5.3986 & 0.0209 & $* *$ \\
EG to FR & 10.3026 & 0.0015 & $* * *$ \\
FR to EG & 0.0494 & 0.8243 & \\
POP to FR & 6.1327 & 0.0138 & $* * *$ \\
FR to POP & 18.0060 & 0.0000 & $* * *$ \\
RED to FR & 2.3429 & 0.1269 & \\
FR to RED & 0.0099 & 0.9208 & \\
POP to EG & 3.2515 & 0.0724 & $*$ \\
EG to POP & 13.9836 & 0.0002 & $* * *$ \\
RED to EG & 0.7176 & 0.3976 & \\
EG to RED & 0.2136 & 0.6443 & \\
\hline
\end{tabular}

364 Statistical significance: $1 \% * * *, 5 \% * *$ and $10 \% *$

365 With the null hypothesis developed, the granger causality test rejected some of the hypotheses and 366 revealed that EFs granger causes FR, EG and POP in West Africa. Also, POP granger causes EFs, 367 FDI granger causes FR, FDI granger causes EG, RED granger causes FDI and vice versa, EG 368 granger causes FR, POP also granger causes FR and vice versa, and POPN granger causes EG at $36910 \%$ significance and vice versa at 5\% significant level. Other results found can be seen on Table 37010.

\section{6. Conclusion and Policy implication}

372 This study evaluated the relationship between environmental quality and renewable energy

373 demand, financial reforms, foreign direct investment, Economic growth Natural resource rent and 374 population. After a series of tests, we found that RED in West Africa has been favorable to their 375 environmental quality, reducing their EF. Also, FR adopted by the region was found to have 376 affected the quality environment as EF was found to increase accordingly. One major finding 377 identified was the negative impact of FDI on EF. This shows that countries in the region have been 
378 focusing on attracting green investments for sustainability purposes. Also, the growth of these 379 economies in the region tends to decline their environmental quality as EG affects EF positively. 380 Using the PMG estimator, the study had some major findings, including EF having a bidirectional 381 relationship with RED, FR, EG and population. Finally, in determining which variables forecast 382 the other, the Granger causality test revealed that EF granger causes FR, EG and Population in 383 West Africa. These findings confirm and go contrary to some researches mentioned in the literature. 384 Based on these revelations, we make the following policy recommendations;

385 In light of the positive impact of RED on environmental quality in West Africa, we advise 386 policymakers to adopt clean technology by expanding renewable energy consumption as a tool to 387 improving environmental quality. Due to the importance of energy in poverty reduction and 388 development, these countries should establish energy development programs, shift to clean and renewable energy consumption to significantly improve environmental quality in these countries. 390 As a result, unless West African governments and related stakeholders exploit the continent's 391 wealth of "clean energy" sources such as solar and geothermal energy and biomass and biogas, 392 tidal and wind power in earnest, the prospect of biodiversity becoming grossly uninhabitable 393 abounds.

394 In addition, our findings suggest that FR has been detrimental to the quality of the environment. 395 Therefore, countries should focus on improving their financial systems, providing more incentives 396 for sustainable and clean energy production projects. They should also support research and 397 development efforts that focus on helping achieve United Nation Sustainable Development Goal 3987 (UN SDG-7). Aside from that, governments should promote financial institutions because they 399 may assist in providing funding for environmentally friendly projects that benefit the countries' 400 surroundings. Limited financial resources hinder renewable energy consumption and sustainability; 
401 however, growth in financial services can assist firms to have access to more funds to embrace 402 sustainable initiatives and investments.

403 Regarding FDIs, the study showed a favorable impact on the environment. However, its sustenance 404 IS key to the long-term development of the region. Therefore, host nations among these regions 405 should be aware of the environmental implications of FDI before introducing foreign investors to 406 their country, especially countries with high EF or biocapacity deficits. To that effect, green 407 investments that enhance recycling and promote a circular economy and sustainability must be 408 attracted and invited into the countries whilst limiting investments that degrade the environment.

409 The Western section of Africa, in particular, is heavily resource dependent. Resources are a major 410 factor in the region's economy. Activities (mining, natural resource exploration, agriculture) and 411 some resources (petroleum, coal, natural gas, among others) stimulate deforestation, depletion of 412 biocapacity, and an increase in EF. Consequently, another strategy to decrease the EF for 413 sustainability is to boost sustainable activities in the natural resource industry and increase the 414 consumption of less polluting sources. The rents generated from the sector must be invested in 415 recyclable projects that offset the resources lost. To will help balance biocapacity or keep it within 416 positive figures.

417 Finally, economic growth has been found to affect environmental quality negatively. These 418 findings have been found in this region and in advanced countries who are now trying their best to 419 reduce $\mathrm{CO}_{2}$ emissions and its associated effects. As these emerging economies aspire to be like 420 the advanced countries, governments should not only focus on just growing their economy but 421 growing it sustainably and familiarizing with the UN SDGs so that their economies can be kept 422 green as they grow.

\section{Authors' contribution}


424 B. Obuobi: Conceptualization, Methodology, Software, Writing-Original draft preparation,

425 Validation, Investigation

426 Y. Zhang: Writing-Reviewing and Editing, Supervision

427 E. Nketiah: Data curation, Writing-Reviewing and Editing

428 G. Adu-Gyamfi: Data curation, Writing-Reviewing and Editing

429 D. Cudjoe: Writing-Reviewing and Editing, Supervision

430 Ethical approval: N/A

431 Consent to participate: N/A

432 Consent to Publish: N/A

433 Funding: This work received no funding

434 Availability of data and materials: Data and materials will be made available upon request

435 Conflict of interest: The authors declare that they have no known competing financial interests 436 or personal relationships that could have appeared to influence the work reported in this paper.

\section{References}

Abokyi, E., Appiah-Konadu, P., Abokyi, F., Oteng-Abayie EF (2019) Industrial growth and emissions of $\mathrm{CO} 2$ in Ghana: the role of financial development and fossil fuel consumption. Energy Rep 5:1339-1353

Acaravci A, Ozturk I (2012) Electricity consumption and economic growth nexus: A multivariate analysis for Turkey. Amfiteatru Econ 14:246-257

Acheampong AO (2018) Economic growth, CO2 emissions and energy consumption: What causes what and where? Energy Econ 74:677-692. https://doi.org/10.1016/j.eneco.2018.07.022

Acheampong AO, Adams S, Boateng E (2019) Do globalization and renewable energy contribute to carbon emissions mitigation in Sub-Saharan Africa? Sci Total Environ 677:436-446. https://doi.org/10.1016/j.scitotenv.2019.04.353

Al-Mulali U, Binti Che Sab CN (2012) The impact of energy consumption and CO 2 emission on the economic and financial development in 19 selected countries. Renew Sustain Energy Rev 16:4365-4369. https://doi.org/10.1016/j.rser.2012.05.017 
Aliyu AK, Modu B, Tan CW (2018) A review of renewable energy development in Africa: A focus in South Africa, Egypt and Nigeria. Renew Sustain Energy Rev 81:2502-2518. https://doi.org/10.1016/j.rser.2017.06.055

Altıntaş H, Kassouri Y (2020) Is the environmental Kuznets Curve in Europe related to the percapita ecological footprint or CO2 emissions? Ecol Indic 113:106187. https://doi.org/10.1016/j.ecolind.2020.106187

Apergis N, Payne JE (2014) Renewable energy, output, CO2 emissions, and fossil fuel prices in Central America: Evidence from a nonlinear panel smooth transition vector error correction model. Energy Econ 42:226-232. https://doi.org/10.1016/j.eneco.2014.01.003

Arshad Ansari M, Haider S, Khan NA (2020) Environmental Kuznets curve revisited: An analysis using ecological and material footprint. Ecol Indic 115:106416. https://doi.org/10.1016/j.ecolind.2020.106416

Aydin C, Esen Ö, Aydin R (2019) Is the ecological footprint related to the Kuznets curve a real process or rationalizing the ecological consequences of the affluence? Evidence from PSTR approach. Ecol Indic 98:543-555. https://doi.org/10.1016/j.ecolind.2018.11.034

Aziz N, Sharif A, Raza A, Rong K (2020) Revisiting the role of forestry, agriculture, and renewable energy in testing environment Kuznets curve in Pakistan: evidence from Quantile ARDL approach. Environ Sci Pollut Res 27:10115-10128. https://doi.org/10.1007/s11356020-07798-1

Balsalobre-Lorente D, Shahbaz M, Roubaud D, Farhani S (2018) How economic growth, renewable electricity and natural resources contribute to $\mathrm{CO} 2$ emissions? Energy Policy 113:356-367. https://doi.org/10.1016/j.enpol.2017.10.050

Bauer N, Mouratiadou I, Luderer G, et al (2016) Global fossil energy markets and climate change mitigation - an analysis with REMIND. Clim Change 136:69-82. https://doi.org/10.1007/s10584-013-0901-6

Baz K, Xu D, Ali H, et al (2020) Asymmetric impact of energy consumption and economic growth on ecological footprint: Using asymmetric and nonlinear approach. Sci Total Environ 718:137364. https://doi.org/10.1016/j.scitotenv.2020.137364

Ben Jebli M, Ben Youssef S (2015) The environmental Kuznets curve, economic growth, renewable and non-renewable energy, and trade in Tunisia. Renew Sustain Energy Rev 47:173-185. https://doi.org/10.1016/j.rser.2015.02.049

Chiu CL, Chang TH (2009) What proportion of renewable energy supplies is needed to initially mitigate CO2 emissions in OECD member countries? Renew Sustain Energy Rev 13:16691674. https://doi.org/10.1016/j.rser.2008.09.026

da Silva PP, Cerqueira PA, Ogbe W (2018) Determinants of renewable energy growth in SubSaharan Africa: Evidence from panel ARDL. Energy 156:45-54. https://doi.org/10.1016/j.energy.2018.05.068

Destek MA, Sarkodie SA (2019) Investigation of environmental Kuznets curve for ecological footprint: The role of energy and financial development. Sci Total Environ 650:2483-2489. https://doi.org/10.1016/j.scitotenv.2018.10.017 
Destek MA, Sinha A (2020) Renewable, non-renewable energy consumption, economic growth, trade openness and ecological footprint: Evidence from organisation for economic Cooperation and development countries. J Clean Prod 242:118537. https://doi.org/10.1016/j.jclepro.2019.118537

Dogan E, Seker F (2016) The influence of real output, renewable and non-renewable energy, trade and financial development on carbon emissions in the top renewable energy countries. Renew Sustain Energy Rev 60:1074-1085. https://doi.org/10.1016/j.rser.2016.02.006

Dong K, Sun R, Hochman G (2017) Do natural gas and renewable energy consumption lead to less $\mathrm{CO} 2$ emission? Empirical evidence from a panel of BRICS countries. Energy 141:1466-1478. https://doi.org/10.1016/j.energy.2017.11.092

Fakher HA (2019) Investigating the determinant factors of environmental quality (based on ecological carbon footprint index). Environ Sci Pollut Res 26:10276-10291. https://doi.org/10.1007/s11356-019-04452-3

Fang G, Wang Q, Tian L (2020) Green development of Yangtze River Delta in China under Population-Resources-Environment-Development-Satisfaction perspective. Sci Total Environ 727:138710. https://doi.org/10.1016/j.scitotenv.2020.138710

Granger CWJ (1969) Investigating Causal Relations by Econometric Models and Cross-spectral Methods. Econometrica 37:424. https://doi.org/10.2307/1912791

Hanif I (2018) Impact of economic growth, nonrenewable and renewable energy consumption, and urbanization on carbon emissions in Sub-Saharan Africa. Environ Sci Pollut Res 25:15057-15067. https://doi.org/10.1007/s11356-018-1753-4

He FS, Gan GGG, Al-Mulali U, Adebola SS (2019) The influences of economic indicators on environmental pollution in Malaysia. Int J Energy Econ Policy 9:123-131. https://doi.org/10.32479/ijeep.7489

Işık C, Ongan S, Özdemir D (2019) Testing the EKC hypothesis for ten US states: an application of heterogeneous panel estimation method. Environ Sci Pollut Res 26:10846-10853. https://doi.org/10.1007/s11356-019-04514-6

Jayanthakumaran K, Liu Y (2012) Openness and the Environmental Kuznets Curve: Evidence from China. Econ Model 29:566-576. https://doi.org/10.1016/j.econmod.2011.12.011

JOYSRI ACHARYYA (2009) Fdi, Growth and the Environment: Evidence From India on Co2 Emission During the Last Two Decades. J Econ Dev 34:43-58. https://doi.org/10.35866/caujed.2009.34.1.003

Katircioğlu, S.T., Taşpinar N (2017) Testing the moderating role of financial development in an environmental Kuznets curve: empirical evidence from Turkey. Renew Sustain Energy Rev 68:572-586

Khan AQ, Saleem N, Fatima ST (2018) Financial development, income inequality, and CO2 emissions in Asian countries using STIRPAT model. Environ Sci Pollut Res 25:6308-6319. https://doi.org/10.1007/s11356-017-0719-2

Khan H, Khan I, Binh TT (2020a) The heterogeneity of renewable energy consumption, carbon emission and financial development in the globe: A panel quantile regression approach. 
Khan SAR, Jian C, Zhang Y, et al (2019) Environmental, social and economic growth indicators spur logistics performance: From the perspective of South Asian Association for Regional Cooperation countries. J Clean Prod 214:1011-1023. https://doi.org/10.1016/j.jclepro.2018.12.322

Khan Z, Ali M, Jinyu L, et al (2020b) Consumption-based carbon emissions and trade nexus: Evidence from nine oil exporting countries. Energy Econ 89:104806. https://doi.org/10.1016/j.eneco.2020.104806

Lau LS, Choong CK, Eng YK (2014) Investigation of the environmental Kuznets curve for carbon emissions in Malaysia: DO foreign direct investment and trade matter? Energy Policy 68:490-497. https://doi.org/10.1016/j.enpol.2014.01.002

Li S, Zhou C, Wang S (2019) Does modernization affect carbon dioxide emissions? A panel data analysis. Sci Total Environ 663:426-435. https://doi.org/10.1016/j.scitotenv.2019.01.373

Liu D, Xiao B (2018) Can China achieve its carbon emission peaking? A scenario analysis based on STIRPAT and system dynamics model. Ecol Indic 93:647-657. https://doi.org/10.1016/j.ecolind.2018.05.049

Liu Y, Hao Y (2018) The dynamic links between CO2 emissions, energy consumption and economic development in the countries along "the Belt and Road." Sci Total Environ 645:674-683. https://doi.org/10.1016/j.scitotenv.2018.07.062

Ma X, Wang C, Dong B, et al (2019) Carbon emissions from energy consumption in China: Its measurement and driving factors. Sci Total Environ 648:1411-1420. https://doi.org/10.1016/j.scitotenv.2018.08.183

Mahesh A, Shoba Jasmin KS (2013) Role of renewable energy investment in India: An alternative to CO 2 mitigation. Renew Sustain Energy Rev 26:414-424. https://doi.org/10.1016/j.rser.2013.05.069

Majeed MT, Mazhar M (2019) Financial development and ecological footprint: A global panel data analysis. Pakistan J Commer Soc Sci 13:487-514

MH P (2004) General diagnostic tests for cross section dependence in panels.

Nathaniel SP, Adeleye N (2021) Environmental preservation amidst carbon emissions, energy consumption, and urbanization in selected african countries: Implication for sustainability. J Clean Prod 285:125409. https://doi.org/10.1016/j.jclepro.2020.125409

Nathaniel SP, Iheonu CO (2019) Carbon dioxide abatement in Africa: The role of renewable and non-renewable energy consumption. Sci Total Environ 679:337-345. https://doi.org/10.1016/j.scitotenv.2019.05.011

Nguyen KH, Kakinaka M (2019) Renewable energy consumption, carbon emissions, and development stages: Some evidence from panel cointegration analysis. Renew Energy 132:1049-1057. https://doi.org/10.1016/j.renene.2018.08.069

Pedroni P (2004) Panel cointegration: Asymptotic and finite sample properties of pooled time series tests with an application to the PPP hypothesis. Econom Theory 20:597-625. 
573

574

575

576

577

578

579

580

581

582

583

584

585

586

587

588

589

590

591

592

593

594

595

596

597

598

599

600

601

602

603

604

605

606

607

608

609

610

Pedroni P (2000) Fully modified OLS for heterogeneous cointegrated panels. Emerald Group Publishing Limited

Rudolph A, Figge L (2017) Determinants of Ecological Footprints: What is the role of globalization? Ecol Indic 81:348-361. https://doi.org/10.1016/j.ecolind.2017.04.060

Sarkodie SA, Ozturk I (2020) Investigating the Environmental Kuznets Curve hypothesis in Kenya: A multivariate analysis. Renew Sustain Energy Rev 117:109481. https://doi.org/10.1016/j.rser.2019.109481

Sarkodie SA, Strezov V (2019) Effect of foreign direct investments, economic development and energy consumption on greenhouse gas emissions in developing countries. Sci Total Environ 646:862-871. https://doi.org/10.1016/j.scitotenv.2018.07.365

Shafiei S, Salim RA (2014) Non-renewable and renewable energy consumption and CO2 emissions in OECD countries: A comparative analysis. Energy Policy 66:547-556. https://doi.org/10.1016/j.enpol.2013.10.064

Shahbaz M, Shahzad SJH, Mahalik MK (2018) Is Globalization Detrimental to CO2 Emissions in Japan? New Threshold Analysis. Environ Model Assess 23:557-568. https://doi.org/10.1007/s10666-017-9584-0

Shahbaz M, Topcu BA, Sarıül SS, Vo XV (2021) The effect of financial development on renewable energy demand: The case of developing countries. Renew Energy 178:1370 1380. https://doi.org/10.1016/j.renene.2021.06.121

Sharif A, Baris-Tuzemen O, Uzuner G, et al (2020) Revisiting the role of renewable and nonrenewable energy consumption on Turkey's ecological footprint: Evidence from Quantile ARDL approach. Sustain Cities Soc 57:102138. https://doi.org/10.1016/j.scs.2020.102138

Shen Y, Su ZW, Malik MY, et al (2021) Does green investment, financial development and natural resources rent limit carbon emissions? A provincial panel analysis of China. Sci Total Environ 755:142538. https://doi.org/10.1016/j.scitotenv.2020.142538

Sinha A, Shahbaz M, Sengupta T (2018) Renewable energy policies and contradictions in causality: A case of Next 11 countries. J Clean Prod 197:73-84. https://doi.org/10.1016/j.jclepro.2018.06.219

Stretesky PB, Lynch MJ (2009) A cross-national study of the association between per capita carbon dioxide emissions and exports to the United States. Soc Sci Res 38:239-250. https://doi.org/10.1016/j.ssresearch.2008.08.004

Tamazian A, Bhaskara Rao B (2010) Do economic, financial and institutional developments matter for environmental degradation? Evidence from transitional economies. Energy Econ 32:137-145. https://doi.org/10.1016/j.eneco.2009.04.004

WHO (2015) No Title

WorldBank (2021) The african continental free trade area. https://www.worldbank.org/en/topic/trade/publication/the-african-continental-free-tradearea. Accessed 24 Aug 2021 
Xu F, Huang Q, Yue H, et al (2020) Reexamining the relationship between urbanization and pollutant emissions in China based on the STIRPAT model. J Environ Manage 273:111134. https://doi.org/10.1016/j.jenvman.2020.111134

Yang, G.F., Sun, T., Wang, J.L., Li XN (2015) Modeling the nexus between carbon dioxide emissions and economic growth. Energy Policy 86:104-117

Zhang M, Yang Z, Liu L, Zhou D (2021) Impact of renewable energy investment on carbon emissions in China - An empirical study using a nonparametric additive regression model. Sci Total Environ 785:147109. https://doi.org/10.1016/j.scitotenv.2021.147109

Zhang P, Cai W, Yao M, et al (2020) Urban carbon emissions associated with electricity consumption in Beijing and the driving factors. Appl Energy 275:115425. https://doi.org/10.1016/j.apenergy.2020.115425

Zhang Y-J (2011) The impact of financial development on carbon emissions: An empirical analysis in China. Energy Policy 39:2197-2203

Zhang Y, Khan SAR, Kumar A, et al (2019) Is tourism really affected by logistical operations and environmental degradation? An empirical study from the perspective of Thailand. J Clean Prod 227:158-166. https://doi.org/10.1016/j.jclepro.2019.04.164

Zhou A, Li J (2019) Heterogeneous role of renewable energy consumption in economic growth and emissions reduction: evidence from a panel quantile regression. Environ Sci Pollut Res 26:22575-22595. https://doi.org/10.1007/s11356-019-05447-w

Zoundi Z (2017) CO2 emissions, renewable energy and the Environmental Kuznets Curve, a panel cointegration approach. Renew Sustain Energy Rev 72:1067-1075. https://doi.org/10.1016/j.rser.2016.10.018 